\title{
La repressió franquista dels funcionaris dels Serveis Correccionals
}

\section{ROBERT DURó FORT}

\author{
Historiador
}

\begin{abstract}
Resum: La repressió franquista que després de 1939 va estendre's a tota la societat per consolidar el règim vencedor de la Guerra Civil, també va afectar els funcionaris de les presons catalanes que, de manera paradoxal, van passar d'escarcellers a presos. Els funcionaris d'aquestes presons, dependents dels Serveis Correccionals de la Generalitat, van ser jutjats i empresonats a causa de la tasca repressiva que havien exercit durant la guerra, i per les denúncies dels presos de la zona republicana que van esdevenir Cautivos por España. El mecanisme repressiu contra aquests funcionaris va ser doble, per mitjà dels consells de guerra, incoats per la justícia militar, i també dels expedients de depuració. L'objectiu d'aquest article, doncs, és realitzar una aproximació global a la repressió que van patir en el seu conjunt el personal de les presons catalanes, per poder observar quina va ser la intensitat d'aquest càstig en els diferents establiments.
\end{abstract}

Paraules clau: Franquisme, Serveis Correccionals, repressió, depuració, postguerra

Abstract: Francoist repression after 1939 was extended to the whole society to consolidate the system regime victory of the Civil War, also affected the Catalan prisons officials that, paradoxically, they move from jailers to prisoners. Officials of these prisons, Correctional Services dependent on the Government, were tried and imprisoned due to the repressive work they had exercised repression during the war, and complaints from the Republican prisoners who became Cautivos por España. The mechanism of repression against these officials was double, through the Councils of war, initiated to military justice, as well as the debug files. The aim of this article, therefore, is to carry out a global approach to the repression they suffered as a whole staff of Catalan prisons, to observe what the intensity of this punishment in different establishments was.

Keywords: Francoism, Correctional Services, repression, purge, post-war

\section{Introducció}

Durant la Guerra Civil la Generalitat de Catalunya va administrar les presons catalanes per mitjà de la Direcció General de Serveis Correccionals i de Readaptació, un organisme dependent de la Conselleria de Justícia creat l'agost de 1936. Els divuit establiments penitenciaris de Catalunya van ser classificats per aquest nou organisme en preventoris o en correccionals en funció dels reclusos que havien d'acollir. Els detinguts que encara no havien processat havien d'estar-se als preventoris, i els reclusos, un cop havien estat condemnats pels tribunals, havien de complir 
la pena imposada als correccionals. A Barcelona hi havia dos preventoris judicials que es corresponien amb la presó Model i amb la secció segona d'aquest preventori que es va habilitar en un convent del carrer de Sant Elies. La resta estaven situats a les ciutats de Girona, Tarragona, Lleida, Reus, Tortosa, Manresa, la Seu d'Urgell, Sabadell, Terrassa, Puigcerdà, Olot, el Vendrell i Sant Feliu de Llobregat, aleshores anomenada Roses de Llobregat. Els correccionals eren els de Figueres, Mataró, Cerdanyola (per als menors d'edat), Vic i el Correccional de Dones de Barcelona.

Els funcionaris d'aquests establiments eren membres del Cos de Presons de la República que havien sollicitat el traspàs al cos autonòmic després de la seva creació l'any 1936, o persones que havien ingressat a aquesta nova organització en les diferents convocatòries de places d'agents correccionals. Des de 1936 fins a 1939 es van fer molts canvis a les plantilles dels preventoris catalans, com destitucions, nous nomenaments o mobilitzacions d'alguns funcionaris; al gener de 1939 hi havia a Catalunya 466 funcionaris dels Serveis Correccionals distribuïts entre les oficines de la direcció general i els diversos establiments preventoris i correccionals. ${ }^{1}$

Un cop finalitzada la guerra totes les persones que van formar part de l'administració republicana van ser objecte de la repressió franquista i entre els cossos d'aquesta administració fidel a la República i al Govern català, els de caire repressiu com la policia, les forces d'ordre públic o els funcionaris de presons van ser perseguits especialment. En l'estudi sobre el Preventori de Lleida on van represaliar-se vuit funcionaris d'una plantilla formada per tretze escarcellers vaig evidenciar aquest nivell alt de repressió dels funcionaris de presons a mans de les autoritats franquistes. ${ }^{2}$ A escala estatal la investigació de Fernando Hernández Holgado també donava unes xifres de repressió molt altes en el cas de la presó madrilenya de Ventas. ${ }^{3}$ Posteriorment, en la tesi doctoral titulada Els Serveis Correccionals de la Generalitat de Catalunya. Guerra i exili d'un funcionari

1 Causa General, caixa 1639, exp. 7, Archivo Histórico Nacional (AHN).

2 Robert Duró FORT, «La represión franquista de los funcionarios de prisiones en Catalunya. El caso de la cárcel de Lleida», dins VI Encuentro de Investigadores sobre el Franquismo (Zaragoza: Fundación Sindicalismo y Cultura CCOO-Aragón, 2007), 867-880.

3 Fernando Hernández Holgado, «Carceleras encarceladas. La depuración franquista de las funcionarias de Prisiones de la Segunda República», Cuadernos de Historia Contemporánea 27 (2005): 271-29o, i Mujeres encarceladas. La Prisión de Ventas: de la República al franquismo, 19311941 (Madrid: Marcial Pons, 2003). 
de presons, Lleida: 1937-1939, vaig ampliar el tema de la repressió als funcionaris de Lleida i vaig recollir algunes dades que permetien creure que aquella repressió es feia extensiva a la resta de presons catalanes com els establiments de la ciutat de Barcelona o d'altres localitats com Vic, Manresa, Girona o Mataró. ${ }^{4}$

Aquest article s'aproxima a la repressió dels funcionaris dels Serveis Correccionals utilitzant el cas estudiat de Lleida, però fent alhora una ràpida visió del que va passar a la resta d'establiments catalans. Per això comprèn un àmbit d'investigació molt ampli, ja que per aprofundir en aquest tema caldria estudiar cada presó i creuar el llistat dels components dels Serveis Correccionals amb els índexs del Tribunal Militar Territorial Tercer de Barcelona, on es troben dipositats els consells de guerra instruïts a Catalunya, i també comparar aquests noms amb les relacions del personal del cos de presons depurat després de 1939. Amb tot, introduint els noms d'aquests funcionaris de presons en algunes bases de dades de la xarxa, com la de represaliats pel franquisme, ${ }^{5} \mathrm{o}$ consultant el BOE, on apareixien els noms dels funcionaris sotmesos a un expedient de depuració, s'ha pogut obtenir una visió més completa d'aquesta repressió. En les fonts utilitzades per establir aquesta primera visió sobre la repressió dels funcionaris de les presons catalanes no hi ha dades dels preventoris de Tortosa, Puigcerdà, Olot, Cervera o de l'establiment de Menors de Cerdanyola del Vallès. En aquests casos, de moment, no s'ha localitzat cap funcionari que hagués patit ni superat cap procés repressiu, però cal tenir en compte que per adscriure els funcionaris als establiments corresponents s'ha utilitzat la nòmina del gener de 1939 i que d'ençà de la creació dels Serveis Correccionals, l'any 1936, van produir-se molts canvis de personal a les plantilles dels Preventoris i Correccionals catalans. En el quadre 1, en apèndix, apareixen els noms dels funcionaris de presons que van patir alguna mena de repressió després de 1939.

Pel que fa a la manera com va dur-se a terme aquesta repressió, deixant ara de banda el nombre de funcionaris que en van ser afectats, les autoritats franquistes van practicar aquesta repressió per una doble via. D’una

4 Robert Duró Fort, Els Serveis Correccionals de la Generalitat de Catalunya. Guerra i exili d'un funcionari de presons, Lleida: 1937-1939 (tesi doctoral, Universitat de Lleida, 2011), 463-466.

5 http://www.pares.mcu.es/victimasGCFPortal. 
banda, els funcionaris de presons van ser jutjats pels consells de guerra que instruïa la justícia militar, generalment incoats a partir de denúncies interposades pels exreclusos, i de l'altra, van ser sotmesos, com la resta de funcionaris de l'Estat, a l'expedient de depuració corresponent. Aquest expedient podia finalitzar amb la readmissió del funcionari o bé amb sancions diverses que anaven des d'un trasllat forçós, fins a la inhabilitació per als llocs de comandament o l'expulsió del cos de presons. Cal tenir en compte, però, que els funcionaris dels Serveis Correccionals que havien ingressat al cos durant la guerra no van ser depurats atès que la Generalitat havia estat abolida i aquests havien estat destituits. Només van depurar-se els que ja eren funcionaris del Cos de Presons de l'Estat abans de la guerra, independentment de si durant el període 1936-1939 havien passat a formar part del cos autonòmic creat a Catalunya.

\section{Investigant el passat. Els noms de la repressió de la postguerra}

Després de l'ocupació de Barcelona per les tropes franquistes les noves autoritats van afanyar-se a posar en funcionament les presons de la capital que havien quedat buides després de la retirada republicana. La repressió va començar de manera parallela a la reorganització de les presons, i va dirigir-se també contra els funcionaris mateixos dels centres penitenciaris, de manera que molts d'ells van passar a ser carceleros encarcelados, manllevant l'expressió de Fernando Hernández Holgado. ${ }^{6}$

Com en tots els àmbits de la rereguarda republicana, les autoritats franquistes volien saber amb detall el que havia succeït a les presons catalanes durant la guerra. Per aquesta qüestió van ser fonamentals totes les informacions recollides per la fiscalia franquista a la Causa General, que investigava els fets que havien tingut lloc a la zona republicana durant la guerra. Davant de la fiscalia van declarar la majoria de funcionaris de presons a mesura que eren detinguts, i també molts dels reclusos que, un cop alliberats, aportant el seu testimoni tenien l'oportunitat de venjar-se contra aquells que els havien custodiat. En l'ambient terriblement repressiu de la postguerra, les autoritats van fomentar la delació de tot aquell que hagués actuat contra del Movimiento Nacional, de manera que moltes

6 Hernández Holgado, «Carceleras encarceladas». 
de les persones que havien estat empresonades durant la guerra van declarar explicant els maltractaments que havien rebut durant el seu captiveri alhora que denunciaven els funcionaris que havien conegut durant aquell temps. Era una pràctica habitual que es mostressin a tots els detinguts i testimonis que declaraven a la Causa General els carnets d'identitat dels funcionaris dels Serveis Correccionals que les tropes franquistes van trobar a les oficines de la presó Model de Barcelona després de l'ocupació de la ciutat a fi que aquells poguessin reconèixer-los i imputar-los delictes i acusacions quan fos el cas i sempre segons el seu criteri. ${ }^{7}$

Els interrogatoris sobre els funcionaris dels Serveis Correccionals no es van limitar als funcionaris de les presons, sinó també a les administratives de les oficines de la direcció general, situades al número 196 del carrer de Londres de Barcelona. D’aquesta manera, el desembre de 1940 van declarar a la Causa General les germanes Dolors i Leonor Gomila Roig, i Maria Antònia Salvà Castellví, a les quals van interrogar sobre els seus companys d'oficina i els càrrecs directius d'aquell departament. ${ }^{8}$

Aquesta tasca d'informació sobre les presons catalanes es va complementar amb la documentació confiscada a les oficines dels Serveis Correccionals feta pel Servicio de Recuperación Documental franquista. De tota la documentació de la Generalitat enviada a Salamanca, amb una clara finalitat repressiva i incriminatòria, cal destacar que els lligalls relatius als Serveis Correccionals són dels més nombrosos. ${ }^{9}$ Contenien informació de tots els preventoris i correccionals catalans. Una part d'aquesta documentació espoliada va ser transferida després al fons de la Causa General, com els carnets d'identitat dels funcionaris ja esmentats, un llistat amb les nòmines dels membres dels Serveis Correccionals del gener de 1939, que contenien el nom dels 466 funcionaris que tenia llavors aquella institució, ${ }^{10}$ i diverses relacions de reclusos de les presons catalanes

7 Causa General, caixa 1904, exp. 1, AHN. Un total de 79 carnets d'identitat dels Serveis Correccionals pertanyents als funcionaris de la presó Model de Barcelona estan dipositats encara en aquest arxiu.

8 Caixa 1.633, exp. 1, AHN.

9 Inventari de la documentació de la Generalitat de Catalunya a l'Archivo Histórico Nacional, Sección Guerra Civil, Generalitat de Catalunya, Departament de Cultura, Barcelona 1992. Dels 213 lligalls de documents del Departament de Justícia, els més nombrosos, un total de 124, corresponen als Serveis Correccionals.

10 Causa General, caixa 1639, exp. 7, AHN. 
— tot plegat, doncs, una informació molt útil per obtenir testimonis i per comprovar quines eren les persones que havien passat per les presons republicanes. Un cop obtinguts els noms dels funcionaris, gràcies als testimonis o a la documentació recuperada, les autoritats intentaven localitzar-los com ho demostren dues cartes del fiscal instructor de la Causa General a l'Ajuntament de Barcelona, en les quals es demanava als encarregats del Padró municipal d'habitants que se'n facilitessin les adreces. ${ }^{11}$

Com era lògic també es van interrogar els funcionaris que havien servit en l'època republicana i gaudien de la confiança de les noves autoritats franquistes. En un escrit del 6 de desembre de 1940, el director de la presó Model de Barcelona facilitava els noms de vint-i-un funcionaris de presons que en aquell moment prestaven servei a les presons de la província de Barcelona i que també ho havien fet durant la guerra. ${ }^{12}$

Les declaracions i acusacions dels antics reclusos van ser molt importants per portar a terme la repressió contra els funcionaris de presons. Moltes persones que havien estat empresonades durant la guerra, després de 1939 van rebre el tractament de Cautivos por España o Excautivos i van organitzar-se en germandats i delegacions nacionals. Una mostra clara del paper actiu que aquestes van tenir en la repressió la trobem en la carta que el president de la Hermandad de Cautivos por España de FETJONS, Jesús Pascual, va escriure al fiscal instructor de la Causa General de Barcelona el desembre de 1940 en la qual facilitava els noms i les adreces dels testimonis disposats a declarar. ${ }^{13}$ Aquells antics reclusos, majoritàriament falangistes i quintacolumnistes, eren el dirigent falangista Luys

11 Caixa 1633, exp. 1, AHN. Els dies 1 i 3 de juliol de 1941 va demanar-se informació sobre els funcionaris Mariano Miret Arechaga, Ernesto Sanchiz Martínez, José Ferrer Raventós, Juan Padilla Molina, Antonio Puig Artola, Francisco Llorca López, Enrique José Català, Francisco Torres Alonso, José García García, Manuel Molist Sala, Ricardo Nolla Verge, Antonio Tormo Alcina, José Farrés Cos, Alfonso Mas Mariages i Luis Rodríguez Martín.

12 Caixa 1.632, exp. 1, AHN. De la presó Model se citava José Moya Rodríguez, Manuel Alejandre Sanz, Francisco Año Ferrus, Manuel Azuara Petrola, Félix González Hernández, José Lobit Fernán dez, Miguel Lozano Herrero, Daniel Luis Gómez, Telesforo Llobet Morato, Federico Muñoz Lama drid, Leopoldo Rubí Álvarez, Adolfo Sánchez Bragado, Enrique Cáceres Fumanal, Nicolás Munipio Barahona, Eduardo Safon Bou, Francisco Álvarez Pauleta; de la presó de dones, Magdalena Larrondo Oquendo, Teresa Suau Gil i Aldemira Mirasierra Gomez, i de la presó de Mataró, Lorenzo Serramitjana Roura.

13 Caixa 1.633, exp. 1, AHN. Jesús Pascual era un dels supervivents de l'afusellament de reclusos que va tenir lloc al monestir del Colell, a la Garrotxa, el gener de 1939. Aquesta experiència l'explica a la seva obra Yo fui asesinado por los rojos (Colell 30-I-1039) (Barcelona: edició de l'autor, 1981). 
Santa Marina; el capità de la Guàrdia Civil Manuel Bravo Montero;14 Fernando Ochoa Urrutia; el falangista René Llanas de Niubó; Fernando Marimón Riera, detingut per pertànyer a la Quinta Columna; María Flaquer Vázquez-Esperanza; Carmen Ramos Señorances; Sabina de González de Carranceja, delegada de la Sección Femenina de FET-JONS; Eduardo Recas, capità de la Guàrdia Civil; Jorge Alegria Mayoral, carlí i conseller de la Vieja Guardia; Paco Saenz Íñigo-Sicilia, falangista i cap del grup clandestí Todos; Víctor Iturrioz Echevarría, membre de la Quinta Columna, i Santiago de Anta Fraile, falangista i membre de la Quinta Columna.

La repressió contra els funcionaris de presons va comptar també amb la particularitat que molts policies de la postguerra o membres dels cossos parapolicials eren també antics reclusos de les presons republicanes. Aquest fet, que responia a una tàctica repressiva clara per atiar l'odi contra els detinguts, queda confirmat en el cas del conegut Rondín Antimarxista de Barcelona diversos integrants del qual, inclòs el fundador mateix del cos, el capità de la Guàrdia Civil Manuel Bravo Montero, havien estat empresonats durant la guerra. ${ }^{15}$

En l'àmbit de les delacions i de les denúncies s'ha de remarcar que si bé és veritat que certs antics reclusos van aprofitar la situació per denunciar els seus escarcellers sia de manera justificada sia obeint a venjances personals, alguns en canvi van demostrar honradesa i humanitarisme, i van declarar favorablement. Destaca, en aquest darrer sentit, el cas del Preventori de Solsona, en el qual cap reclús no va ni denunciar ni declarar en contra dels funcionaris de la Generalitat després de la guerra, un fet que demostra, a més, el bon tracte que els presos deurien haver rebut en aquell establiment penitenciari. ${ }^{16}$

14 Vegeu Manel Risques \& Carles Barrachina, Procés a la Guàrdia Civil: Barcelona, 1939 (Barcelona: Pòrtic, 2001).

15 Bravo Montero era fill del cap de policia Manuel Bravo Portillo, un destacat perseguidor dels sindicalistes a Barcelona durant els anys del pistolerisme. El cap del Rondín Antimarxista fou un personatge temut durant la primera postguerra fins que va caure en desgràcia a causa d'un obscur cas d'espionatge pel qual fou condemnat i degradat. Sobre aquest personatge pot consultar-se l'obra de José Luis Cervero, Los rojos de la Guardia Civil (Madrid: La Esfera de los Libros, 2006), 319-333, i l'obra de Santiago TARín, Barcelona en rosa y negro: la crónica policíaca y sentimental del siglo $X X$ (Barcelona: Plaza \& Janés, 2002), 83-121.

16 Robert Duró ForT, Guerra i exili d'un funcionari de presons. El Preventori Judicial de Lleida-Solsona, 1937-1939 (Lleida: Pagès editors, 2012), 268. 


\section{Les detencions}

Després de l'ocupació franquista de Barcelona van fer-se les primeres detencions de funcionaris de presons en els seus llocs de treball. Aquests casos eren els de funcionaris antics. Molts d'ells ho eren des del temps de la monarquia, s'havien limitat a seguir en el seu lloc de feina durant la guerra i van presentar-se a les noves autoritats franquistes creient que aquesta actitud no mereixia sanció. Encara que existeixen casos particulars, la majoria dels que havien estat només funcionaris dels Serveis Correccionals, i per tant havien esdevingut escarcellers durant la guerra, van retornar als seus domicilis o van fugir cap a la frontera amb la població civil i les tropes republicanes en retirada. Al Preventori judicial de Barcelona hi va haver l'únic cas d'un funcionari dels Serveis Correccionals que després de la guerra va continuar prestant servei a la mateixa presó sense patir cap mena de represàlia. Es tractava d'Alfons Caceres Fumanal, que ingressà als Serveis Correccionals el desembre de 1937. Després de l'ocupació franquista, gràcies a l'informe favorable del cap dels reclusos feixistes de la presó, el coronel Morillo, Caceres va ser nomenat funcionari de la Model per les noves autoritats en reconeixement al bon tracte que aquest havia dispensat als reclusos de dretes. ${ }^{17}$

Evidentment, els càrrecs de més responsabilitat dels Serveis Correccionals van marxar cap a l'exili per evitar la repressió. Aquest va ser el cas del director general, Rafael Tasis i Marca, que va exiliar-se a França i que no retornà a Catalunya fins l'any 1948, o del seu successor, Joan de Garganta Fàbrega, que va exiliar-se a Sud-Amèrica i mai més tornaria a Catalunya. ${ }^{18}$ També va marxar cap a França el secretari dels anteriors, el manresà Vicenç Prat Brunet, que va ser internat al camp de Bram. Pel que fa als directors dels diversos preventoris i correccionals catalans, van fugir Isabel Peyró Polo, directora del Correccional de Dones de Barcelona; ${ }^{19}$

17 Causa General, caixa 1633, exp. 1, AHN.

18 A l'exili francès Tasis va escriure les memòries del seu pas per la direcció general de Serveis Correccionals: Les presons dels altres. Records d'un escarceller d'ocasió (Barcelona: Pòrtic, 1990).

19 Isabel Peyró era militant del POUM i companya del dirigent d'aquest partit Enric Adroher, Gironella. Tal com es recull en l'obra de Fernando Hernández Holgado, La prisión militante: las cárceles franquistas de mujeres de Barcelona y Madrid (1939-1945) (Madrid: Universidad Complutense de Madrid, 2011), 47. 
Joan Regués Bonany, director del Preventori Judicial número 2 de Barcelona; Eduard Costa Julià, director dels Preventoris de Lleida i Solsona; Joan Rius Gatell, director del Preventori de Girona; Feliu Prats Granyé, director del Preventori de Terrassa; Àngel Pedret Segura, director del Preventori de Manresa, i Lluís Grau Castells, director del Correccional de Vic fins a l'abril de 1938. Pel que fa als funcionaris d'altres establiments, consta la detenció de Joan Enric Llovera Martí, director del Pavelló Hospital; la de José Vicente Sebastián, director del Correccional de Mataró; la de Josep Castan Velázquez, director l'any 1936 del Preventori de Roses de Llobregat, i la de Pere Llamapallas Camarasa, administrador del Correccional de Vic.

Per norma general, les autoritats franquistes no es van refiar dels funcionaris que s'havien quedat a esperar la seva arribada, i si no en podien contrastar l'adhesió, els apartaven del servei fins que no n'obtinguessin la informació necessària que la demostrés. Així doncs, les primeres detencions no es van fer esperar i, per exemple, el 30 de gener de 1939, quatre dies després de l'ocupació franquista de la ciutat, es va detenir el funcionari Narcís Garcés Fredes amb altres tres funcionaris més del Preventori Judicial número 2, que corresponia a la presó habilitada al carrer de Sant Elies. ${ }^{20}$ A la presó Model el funcionari Antoni Rueda Garcia, que des de l'ocupació de la ciutat s'havia presentat voluntàriament cada dia al centre, va ser detingut quan un policia que havia estat empresonat a Lleida el va reconèixer com un dels funcionaris d'aquella presó. ${ }^{21}$

Al Correccional de Dones de Barcelona, on no s'havien conservat els fitxers amb els noms de les funcionàries, va detenir-s'hi la sotsdirectora, a qui es va obligar que facilités els noms i les direccions de totes les funcionàries. Amb aquesta informació, el 17 de febrer de 1939 es van detenir i empresonar vint-i-una guardianes. ${ }^{22}$ Es tractava d'una detenció massiva de totes les funcionàries que no havien fugit a l'exili que tenia un caràcter preventiu atès que una de les detingudes, Magdalena Larrondo, va ser confirmada com a cap de serveis per la nova direcció franquista el mateix

20 «Procedimiento Sumarísimo Ordinario n. ${ }^{\circ}$ 5.360 instruido contra Narciso Garces Fredes», Archivo del Tribunal Militar Territorial Tercero (ATMTT).

21 "Sumarísimo de urgencia n. ${ }^{\circ} 188$ seguido contra Antonio Rueda García», ATMTT.

22 Prisión Provincial de Mujeres (PPM), unitat d'installació 246, ANC. La detenció d'aquestes funcionàries és comentada a l'article d'HernándEZ HolgADo, «Carceleras encarceladas», 281. 
dia del seu alliberament. ${ }^{23}$ Del total de quaranta-sis funcionàries que integraven la plantilla del centre penitenciari, només dotze, entre les quals cal comptar la directora, Isabel Peyró, no es van poder capturar perquè havien fugit i van ser declarades rebels. Les trenta-quatre restants van ser detingudes però van sortir de la presó en llibertat provisional al cap de poc temps mentre s'instruïa el consell de guerra que les havia de jutjar i que va començar el 20 de febrer. ${ }^{24} \mathrm{El} 22$ d'octubre de 1943 totes les acusades en el procediment judicial, excepte les dotze declarades rebels, van obtenir la llibertat definitiva després que es decretés el sobreseïment de la causa.

També va ser detingut el que havia estat director de la presó de Sant Feliu de Llobregat, Josep Castan Velázquez, acusat d'haver permès la sortida de la presó, l'any 1936, d'un grup de presos considerats feixistes que un escamot armat va treure de la presó i va assassinar als afores de la ciutat. La captura de Josep Castan per la policia, com succeïa amb altres persones que havien tingut càrrecs a l'administració republicana, va ser anunciada i difosa per les autoritats franquistes per fer publicitat de la seva eficient tasca policial. El diari La Vanguardia Española va publicar el 2 de maig de 1939 aquesta detenció amb el següent títol: «Detención del Director de la Cárcel de Lérida en la época roja», per continuar amb un breu text que deia: «Ha sido detenido y puesto a disposición del auditor de Guerra, José Castany [sic] Velázquez, director de la Cárcel de Lérida durante el dominio rojo».25 Però per aconseguir aquest objectiu propagandístic, la notícia publicada falsejava la categoria de Josep Castan, al qual s'identificava com a director de la presó de Lleida, quan en realitat només n'havia estat el cap de serveis. A més, se n'obviava la condició de director de la presó de Sant Feliu de Llobregat, preventori en el qual tenia més responsabilitats que no pas al de Lleida. Que Lleida fos una capital de província i que el director d'aquell establiment, Eduard Costa, no hagués estat encara capturat, fa pensar que les autoritats franquistes volien donar a aquella detenció una major ressonància.

El funcionari i mossèn Joan Fuster Cuyàs, que s'havia quedat a esperar l'arribada de les tropes franquistes com a director provisional del preven-

23 Hernández Holgado, «Carceleras encarceladas», 281.

24 «Sumarísimo de urgencia n. ${ }^{\circ}$ 1.093, instruido contra Lidia Gonzalez Casas y 45 más», ATMTT.

25 La Vanguardia Española, 2 maig 1939, 5. 
tori de Girona hi va ser empresonat el 13 de febrer de 1939. També van detenir-se dos funcionaris més del mateix centre, Rafael Espejo Gabarrón i Josep Ventura Barceló, acusats juntament amb Fuster d'haver lliurat tretze reclusos d'aquella presó a les forces republicanes en retirada, que van assassinar posteriorment als afores de la ciutat, a la zona de la Tallada. ${ }^{26}$

Les detencions dels funcionaris dels Serveis Correccionals vistes fins al moment van fer-se pocs dies o pocs mesos després que les tropes franquistes ocupessin el territori català. Aquests casos corresponen als que van declinar la fugida cap a l'exili i van esperar al seu lloc de treball, o a la seva ciutat, l'arribada dels vencedors. Però poc temps després d'aquestes primeres detencions se'n van produir de noves, que corresponien a les dels agents que havien marxat a l'exili i que després de l'ocupació total de Catalunya, o fins i tot una vegada finalitzada la guerra, van retornar a casa. Aquest fou el cas, per exemple, del director del Preventori de Lleida i Solsona, Eduard Costa, que va ser detingut el dia 11 de juliol de 1939, quan feia quatre mesos que havia tornat de França. Durant aquell temps, Costa va reprendre la seva vida anterior a l'esclat de la guerra i reingressà a la seva antiga feina d'administratiu en una empresa metallúrgica de Barcelona amagant la seva condició de funcionari dels Serveis Correccionals. Segons l'informe policial, Costa va ser detingut en un bar pel policia Antonio Gaspar, un exreclús del Preventori de Lleida que el va reconèixer i que casualment era el mateix que havia identificat i detingut el funcionari Antonio Rueda. ${ }^{27}$

Joan Regués, director del Preventori Judicial número 2 de Barcelona, que els últims dies de la guerra havia estat nomenat administrador del Correccional de Figueres, també va ser detingut quan va retornar de França el dia 1 d'agost de 1939. La detenció va publicar-se al diari La Vanguardia Española, en la secció d'Ordre Públic. La notícia començava amb el títol destacat «Un sujeto que entregó a varios detenidos para que fuesen asesinados» i atribuïa a Regués la responsabilitat, mentre era oficial de presons a Lleida, d'haver lliurat un grup de reclusos que posteriorment foren assassinats per «los esbirros del POUM». En el text també es

26 Josep Clara, Girona 1939: Quatre sentències de mort (Barcelona: Publicacions de l'Abadia de Montserrat, 2001), 71.

27 «Sumarísimo de urgencia n. ${ }^{\circ} 3.500$ seguido contra Eduardo Costa Juliá», ATMTT. 
culpava aquest oficial d'haver ascendit dins de l'escalafó del Cos de Presons gràcies a la seva «incondicionalidad con que servía a los dirigentes rojos», i finalitzava explicant el motiu que n'havia facilitat la detenció: «Al ser liberada Cataluña por el invicto Ejército del Caudillo, huyó a Francia, de donde ha regresado, según sus afirmaciones, por preferir estar en las cárceles de España que en los campos de concentración franceses». ${ }^{28}$ Regués va prestar declaració davant el capità de la Guàrdia Civil Manuel Bravo Montero, cap del Rondín Antimarxista, i encara que a la declaració policial no es mencionava aquest fet, ambdós personatges ja s'havien conegut amb anterioritat en unes circumstàncies totalment oposades, quan Bravo Montero era reclús de les presons de Vic i Sant Elies de les quals Regués havia estat director. Aquest, però, no era l'únic policia que coneixia a Regués. Un dels dos agents que van portar-lo a declarar davant Bravo Montero, l'agent Máximo Ilarri Gambra, també havia estat empresonat a Sant Elies quan Regués n'era el director, a causa de la seva implicació en la insurrecció militar de 1936. Fins i tot és probable que l'altre policia, Joan Tella Baroy, també recordés Regués arran de la seva estada al Preventori de Mataró on fou empresonat per formar part de la Quinta Columna. ${ }^{29}$ Com ja s'ha vist, també eren exreclusos els policies que van detenir Antoni Rueda o Eduard Costa. En aquests casos, doncs, no existia cap dificultat per localitzar testimonis que identifiquessin o declaressin contra els funcionaris de presons detinguts perquè els mateixos agents que practicaven les detencions podien fer-ho.

\section{Els consells de guerra}

En els processos oberts contra els funcionaris de presons els motius de denúncia més corrents van ser el maltractament infligit als presos i haver permès que es lliuressin reclusos als milicians o a algunes forces d'ordre públic que després van assassinar-los, com va passar a les presons de Lleida, la Seu d'Urgell, Sant Feliu de Llobregat i a la de Girona. Aquesta darre-

28 La Vanguardia Española, 6 oct. 1939, 2. Com s'ha vist anteriorment la publicació d'aquestes detencions servia per ressaltar l'eficiència de la policia però també perquè els que reconeixien el nom dels detinguts poguessin anar a comissaria a testificar.

29 La detenció de Joan Tella i un grup de persones acusades de formar part de la Quinta Columna de Barcelona va publicar-se a Mi Revista. Ilustración de Actualidades, 1 feb. 1937, 8. 
ra era l'acusació més greu que podia rebre un funcionari de presons, i per aquesta raó el Codi de Justícia Militar impedia de manera expressa que a cap condemnat a mort per aquest càrrec se li pogués commutar la pena per la de trenta anys de presó. ${ }^{30}$ També s'acostumava a acusar els funcionaris que havien fugit cap a França durant l'ocupació franquista de Catalunya d'abandonar els reclusos o el servei. Aquesta va ser l'acusació emesa als integrants de la plantilla del Preventori de Lleida que, a les acaballes de març de 1938, va rebre l'ordre de la direcció general de Serveis Correccionals d'evacuar la ciutat abans de l'arribada de les tropes ocupants per dirigir-se a la localitat de Solsona.

És important comentar que, al marge de l'acusació d'haver permès la sortida de la presó de reclusos que serien després assassinats, la resta de càrrecs contra els funcionaris de la Generalitat eren poc consistents perquè a diferència de les atrocitats comeses en altres centres de reclusió que s'escapaven del control de la Generalitat, com les txeques o els camps de treball del Servicio de Investigación Militar (SIM), els funcionaris dels preventoris i correccionals catalans no van cometre ni assassinats ni tortures. A partir de 1939, van aparèixer nombrosos relats d'exreclusos que narraven el seu captiveri durant la guerra i que únicament feien referència a l'estada a les txeques o als camps de treball del SIM, i no en canvi al seu pas per les presons de la Generalitat, un silenci que deixava entreveure que el tracte dispensat als reclusos de les presons catalanes hauria estat bo. ${ }^{31}$ En referència a la Model de Barcelona i al règim a què estaven sotmesos els seus interns, un reclús d'ideologia feixista, Miguel Sabater, va escriure després de la guerra:

Acostumbrados a la vista de las bayonetas y fusiles, a las formaciones y cornetazos, a gritos, palos e incomunicaciones absolutas en chekas y cárceles del

30 Joan Cor baLÁN GIL, Justícia, no venjança: Els executats pel franquisme a Barcelona, 1939-1952 (Valls: Cossetània Edicions, 200o), 63.

31 Alguns d'aquests relats sobre el captiveri durant la guerra són: Félix Ros, Preventorio D (ocho meses en el SIM) (Barcelona: Yunque, 1939); Jesús PASCUAL, Yo fui asesinado por los rojos (Colell 30-I1039) (Barcelona: edició de l'autor, 1981); Martín InGLÉs, Las checas de Catalunya. Bajo las garras del SIM (Barcelona: [s.n.] 1939); Miguel SABATER, Estampas del cautiverio rojo. Memorias de un preso del SIM (Barcelona: Librería Religiosa, 1940); Eduardo Car ballo, Prisión flotante (Barcelona: Ediciones B y P, [s.d.]); R.L. Chacón, Por qué hice las "Checas" de Barcelona. Laurencic ante el Consejo de Guerra (Barcelona: Solidaridad Nacional, 1939). 
S.I.M. se comprenderá que se tuviese a la Modelo como la Meca del bienestar, como un séptimo cielo (sin huríes, naturalmente) y que constituyese el llegar a sus muros, la aspiración de todos nosotros. Quien únicamente haya gustado la Modelo, desconoce en absoluto el régimen corriente de las cárceles rojas. ${ }^{32}$

Així doncs, en els procediments contra els funcionaris dels Serveis Correccionals, moltes denúncies feien referència al funcionari mateix o a les seves circumstàncies personals i no tant al tracte que havia donat als reclusos. Algunes d'aquestes acusacions alludien la manera com l'acusat havia obtingut el càrrec de funcionari de presons o la seva ideologia política, com va ser el cas d'Eduard Costa, a qui van acusar d'haver estat nomenat director del Preventori de Lleida «debido a sus ideas netamente marxistas y de completo acuerdo con el régimen rojo».33 Quan, en canvi, no hi havia prou motius de denúncia es formulaven acusacions com la dirigida a un funcionari perquè «dispensó en ocasiones a los presos derechistas un trato áspero y desconsiderado y dirigiéndose hacia ellos en tono descompasado e insultante, pronunciando a veces palabras soeces y blasfemias y exteriorizando su simpatía por la causa marxista, no constando que maltratase de obra a ningún recluso, si bien aprobaba los desmanes que se cometían».34

Entre els casos estudiats, no deixa de ser sorprenent l'acusació que motivà la detenció de l'agent dels Serveis Correccionals Antonio Rueda. Aquest funcionari de Barcelona va ser destinat a Lleida on va prestar servei durant tres mesos. Després de l'ocupació franquista de la ciutat va servir gairebé la resta del temps a la Model on cap dels reclusos no va denunciar-lo, però va ser detingut perquè no havia permès l'evasió de cinc reclusos de Lleida pocs dies abans que hi arribessin les tropes franquistes. L’acusació que va rebre Rueda era comprensible des de l'òptica franquista i demostrava perfectament com s'aplicava la justícia al revés, això és, sancionant unes accions que en el moment d'executar-les no representaven cap infrac-

32 SABATER, Estampas del cautiverio rojo, 16o; citat a Francesc BADIA, Els camps de treball a Catalunya durant la guerra civil (Barcelona: Publicacions de l'Abadia de Montserrat, 2001), 51.

33 Procedimiento Sumarísimo de Urgencia n. ${ }^{0} 3.500$ seguido contra Eduardo Costa Juliá», ATMTT.

34 "Procedimiento Sumarísimo Ordinario n. ${ }^{\circ} 5.360$ instruido contra Narciso Garces Fredes», ATMTT. 
ció de la llei vigent. I encara més: castigar un funcionari de presons, la primera obligació del qual hauria de ser custodiar els reclusos al seu càrrec, perquè no havia deixat escapar uns presos és una contradicció flagrant..$^{35}$

Una altra acusació que no estava vinculada al maltractament físic dels reclusos és la que va rebre el director del Preventori número 2 de Barcelona, Joan Regués, de part del capità Bravo Montero, el qual declarà: «Regués demostró su intransigencia cuando en el año 1938 el gobierno rojo autorizó los preceptos religiosos no obstante tener la orden se negó a facilitarlos». ${ }^{36} \mathrm{El}$ cap del Rondín Antimarxista acusava també el director d'aquella presó de deixar-se dominar pels reclusos de la FAI, mentre que al mateix temps reconeixia que s'havia portat bé amb tots els reclusos. La inconsistència d'algunes acusacions queda demostrada en el cas de la funcionària del Preventori de Lleida i del Correccional de Dones de Barcelona, Rosa Teresa, a qui es va acusar tan sols d'haver servit a la presó de dones de Barcelona però sense que es pogués demostrar que hagués comès cap acte delictiu concret. ${ }^{37}$

En tots aquests processos les acusacions formulades eren corroborades per diferents testimonis a petició del jutge instructor. En aquestes declaracions, els antics reclusos, generalment partidaris del bàndol franquista, van acusar els funcionaris de presons de les privacions i maltractaments soferts durant el seu captiveri, de l'extrema rigidesa del règim carcerari o dels abusos arbitraris rebuts a la presó. Encara que moltes d'aquelles acusacions estaven ben fonamentades, cal considerar que moltes d'altres eren motivades per un afany de venjança contra aquells funcionaris i que a causa d'això tendien a ser exagerades o directament falses. Tot i que no pot dubtar-se de l'autenticitat de les declaracions d'aquells antics reclusos, després de la guerra molts van aprofitar-se de la posició de poder obtinguda devers els seus antics guardians.

Encara que diversos reclusos van declarar en contra dels acusats, un gran nombre d'antics presos van presentar en aquests consells de guerra un testimoni favorable, negant els maltractaments i aportant exemples concrets del bon tracte que havien rebut dels guardians durant el seu

35 Duró Fort, Guerra i exili d'un funcionari, 282.

36 «Procedimiento Sumarísimo Ordinario n. ${ }^{\circ} 14.027$ seguido contra Juan Regues Bonany», ATMTT.

37 «Sumarísimo de urgencia n. ${ }^{\circ}$ 1.093, instruido contra Lidia Gonzalez Casas y 45 más», ATMTT. 
captiveri. Els arguments més repetits pels antics reclusos per justificar les bones atencions a la presó eren que se'ls hagués permès de rebre visites de familiars, que se'ls hagués concedit trasllats de la presó a l'hospital o que se'ls proporcionés menjar de manera extraordinària. Aquesta era, per posar-ne un exemple, la declaració favorable que el funcionari dels Preventoris de Sant Feliu de Llobregat, Lleida i el Preventori Judicial número 2 de Barcelona Josep Castan va rebre de part d'un dels seus reclusos:

En contra de las órdenes que me consta tenia recibidas el citado funcionario por su cuenta nos daba toda clase de facilidades hasta incluso casi como si estuviéramos en libertad, en diversas ocasiones nos animaba a los allí detenidos que tuviéramos paciencia que pronto llegarían las fuerzas de nuestro Glorioso Ejército Nacional y nos liberarían. Como la comida que nos suministraban era escasísima se esmeraba de gran manera para proporcionarnos lo que podía cuando a recursos y alimentos interesándose cuando algún recluso caía enfermo de gran manera para que fuese evacuado al hospital cosa que en aquellos tiempos los marxistas concedían como un verdadero privilegio..$^{38}$

Rossend Codina Ramon, funcionari del Correccional de Vic, i dels Preventoris de Manresa, Lleida i Barcelona, que havia estat escarceller del capità Bravo Montero, va rebre el testimoni favorable de la germana d'aquest, Josefina Bravo Montero, i del secretari del Rondín Antimarxista, el policia César Rodrigo, que va declarar: «desconoce en absoluto su ideologia política habiéndose portado siempre con los reclusos de aquella prisión perfectamente, siendo uno de los pocos guardianes que se mostraban condescendientes con ellos aún sabiendo su ideología nacionalista, que todos los favores de que eran objeto los reclusos por parte de dicho encartado los realizaba desinteresadamente». 39

Lògicament alguns funcionaris dels Serveis Correccionals que havien ingressat al cos durant la guerra, com per exemple Rossend Codina, van ser condemnats per l'actuació política anterior al seu ingrés als Serveis Correccionals; en aquests casos la repressió no està relacionada, almenys

38 «Procedimiento Sumarísimo de Urgencia n. ${ }^{0} 7.274$ seguido contra José Castan Velázquez», ATMTT.

39 «Procedimeinto Sumarísimo de Urgencia n. ${ }^{\circ} 14.602$ seguido contra Rosendo Codina Ramon», ATMTT. 
directament, amb la seva condició de funcionaris de presons. Així doncs, la repressió d'aquests funcionaris s'assimilaria, segons l'estudi de Manel Risques, a la que van rebre els Mossos d'Esquadra que també havien ingressat al cos durant la guerra, i que haurien estat processats pel seu passat polític i per la seva participació en organismes revolucionaris..$^{40}$

No hi dubte de les causes que motivaren la repressió en els casos que s'han pogut consultar com, per exemple, el ja comentat dels funcionaris del Preventori de Girona que apareix en el llibre de Josep Clara dedicat al procediment seguit contra un dels seus funcionaris, el capellà Joan Fuster, esmentat més amunt. ${ }^{41}$ Fuster fou nomenat director accidental d'aquell establiment en els últims dies de la guerra i condemnat a mort per un consell de guerra franquista. La seva condició de sacerdot i l'ajuda de les jerarquies eclesiàstiques li van permetre d'obtenir l'indult i la pena capital fou commutada per la de trenta anys de presó. Aquest, però, no va ser el cas dels altres dos funcionaris de Girona condemnats en la mateixa causa que Fuster, Rafel Espejo Gabarron i Josep Ventura Barceló, que van ser executats el 12 d'agost de $1939 .{ }^{42}$ També va ser jutjat en un consell de guerra i condemnat a mort el primer director del Preventori de Girona, Manuel Suárez García-Labrador. A la mateixa ciutat fou afusellat el 10 de març de 1941 Pere Llampallas Camarasa, antic director de la presó d'aquella ciutat, de la de Tarragona i del Correccional de Vic. ${ }^{43}$ Llampallas es trobava empresonat a la Model de Barcelona a causa d'una evasió de reclusos que va tenir lloc a Vic mentre n'era director, i tal com explica Pelai Pagès: «Franco se'l va trobar a la presó i l'acabaria afusellant amb la publicitat que el cas d'un escarceller roig requeria».44

Del Correccional de Vic va ser denunciat per l'exreclús i testimoni de la Causa General, Víctor Iturrioz, el funcionari José Hormigo Sánchez com un «individio desalmado y un perfecto canalla», encara que no te-

40 Manel Risques Cor Bella, Identitat democràtica o tradició espanyolista? La repressió sobre els Mossos d'Esquadra a la postguerra (Barcelona: Edhasa, 2003), 46-47.

41 Clara, Girona 1939, 59-105.

42 Ibídem,175-176.

43 Ibídem, 64.

44 Pelai Pagès, La presó Model de Barcelona: història d'un centre penitenciari en temps de guerra, 1936-1939 (Barcelona: Publicacions de l'Abadia de Montserrat, 1996), 380. La notícia de la detenció de Llampallas pel Rondín Antimarxista que es va publicar a La Vanguardia Española el 8 de juny de 1939 . 
nim constància ni de la seva detenció ni del seu processament. ${ }^{45}$ Del Preventori de Lleida va jutjar-se per respondre dels assassinats de reclusos dels primers mesos de la guerra el director Joaquín Morcillo Núñez i l'administrador Julio Aragonés Marín, ambdós membres del cos de Presons estatal. Els dos directius havien estat destituïts per la Generalitat a primeries de 1937 i aquest fet, sens dubte, representà un atenuant quan van ser jutjats pels franquistes. Morcillo va ser absolt, encara que expulsat del cos de presons, i Aragonés va ser condemnat a sis anys d'inhabilitació, encara que tots dos van ser readmesos el 1946 i el 1949, respectivament. ${ }^{46}$ Del mateix preventori va jutjar-se'n també el director, Eduard Costa, que tot i no ser acusat de la mort de cap reclús fou condemnat a 12 anys de presó.

Del Preventori Judicial de Barcelona tenim coneixement de l'afusellament de Francesc Vilà Costafreda, un barber natural de Bellpuig que ingressà als Serveis Correccionals el desembre de 1937 i que va ser condemnat a mort per un consell de guerra i executat el 4 de març de $1939 .{ }^{47} \mathrm{Del}$ mateix establiment, encara que en referència a la seva actuació a Lleida, va ser condemnat a 12 anys de presó Antoni Rueda García.

Gràcies al sumari instruït a Narcís Garcés, que va ser condemnat a 12 anys de presó, tenim coneixement d'altres funcionaris del Preventori Judicial número 2 de Barcelona que van ser processats, com Josep Bastús Ribera, Sebastián Nicolau Fernando, Francisco Oromí Capell i José Miralles Gausachs, entre altres. ${ }^{8}$ També va ser processat el director d'aquell establiment, Joan Regués Bonany, que va ser absolt encara que posteriorment no va poder superar el seu procés de depuració i va ser expulsat del cos de presons, un cas que exemplifica la perfecta complementarietat dels instruments repressius del franquisme.

Del Correccional de Dones de Barcelona van ser processades quaranta-cinc funcionàries, encara que finalment es va sobreseure la causa contra elles amb l'excepció de les que havien fugit i havien estat declarades

45 Causa General, caixa 1633, exp. 1, AHN.

46 Fondo de la Dirección General de Instituciones Penitenciarias (FDGIP), expedients de depuració de Julio Aragonés Marín i Joaquín Morcillo Núñez, Archivo General del Ministerio de Interior (AGMI).

47 Corbalán Gil, Justícia, no venjança, 348.

48 «Procedimiento Sumarísimo Ordinario n. ${ }^{\circ} 5.360$ instruido contra Narciso Garces Fredes», ATMTT. 
rebels: Isabel Peyró Polo, Josefa Gómez Márquez, Josefa Coll, Concepción Sola, Josefa Barrera, Rosa Sanz, Pura García Gómez, Josefina Mani de Peypoch, Margarita López, Josefina García Pastor i Joaquina Mallorquín. ${ }^{49}$ El dia 10 de febrer de 1943, un edicte de la Justícia Militar requeria a les anteriorment citades i a Vicenta Pérez Devesa, Dolores Servent, Francisca Baquero i Eleonor Barnolas que es presentessin al Jutjat Militar número 7 de Barcelona..$^{50}$

Del Preventori Judicial de Mataró van jutjar-se almenys tres dels seus funcionaris - Nicolás Verdaguer Claus, Ernest Clariana Josep i Enrique Ferrer Llagostera-, encara que desconeixem el resultat del processament i si el desencadenant era la seva actuació com a funcionaris. ${ }^{51}$ Segons les informacions de la Causa General, també van ser detinguts altres funcionaris del mateix centre, encara que no disposem de dades per saber si van ser processats, com el director José Vicente Sebastián, abans director de la Presó Model, l'administrador Eduard Meléndez i Gardenyes, Macario Roure Julve, Juan Prats Prats i Juan Sariol Español.52

Josep Castan Velázquez, director de l'establiment de Sant Feliu de Llobregat va ser condemnat a mort el dia 19 de juliol de 1943, per la seva implicació en l'assassinat de catorze reclusos d'aquella presó l'any 1936. Afortunadament, un segon procediment judicial, celebrat el 24 de febrer de 1944, va rebaixar la condemna a 12 anys de reclusió i a la inhabilitació absoluta per exercir de funcionari de presons. ${ }^{53}$

Joan Espinalt Berenguer, funcionari del Preventori de Manresa, va ser detingut per les autoritats franquistes el febrer de 1939. La seva captura, com la de molts dels seus companys, va ser notícia a La Vanguardia Española, on s'explicava que «tomó parte en el incendio y saqueo de iglesias y conventos, y ocupó el cargo de consejero de Abastecimientos y oficial de prisiones».54

49 «Sumarísimo de urgencia n. ${ }^{\circ}$ 1093, instruido contra Lidia Gonzalez Casas y 45 más», ATMTT.

50 La Vanguardia Española, 10 feb. 1943, 8.

51 David Martínez Fiol, La sindicació dels funcionaris de la Generalitat de Catalunya (19311939) (tesi doctoral, Universitat Autònoma de Barcelona, 2007), 748.

52 Causa General, caixa 1632, exp. 2, AHN.

53 «Procedimiento Sumarísimo de Urgencia n. ${ }^{\circ} 7.274$ seguido contra José Castan Velázquez», ATMTT.

54 La Vanguardia Española, 16 feb. 1939, 9. 
Del Preventori de Sabadell tenim constància de la detenció del funcionari Higini Navarro Abadal. 55 En referència al Preventori de Terrassa, una carta de l'Ajuntament dirigida al fiscal de la Causa General explicava que la presó havia tingut tres directors i diversos oficials i guardians dels quals se n'ignorava el nom, i aportava com a única informació el testimoni del funcionari Francisco González Sánchez que es quedà a custodiar els reclusos feixistes durant la retirada republicana i que en aquells moments no estava detingut..$^{56}$

Del Pavelló de reclusos de l'Hospital de Sant Pau es van detenir Emili Morató Vives i el director de l'establiment, Joan Enric Llovera Martí, que havia exercit el mateix càrrec als Preventoris de Lleida, Tarragona, Reus i Manresa. En el cas de Llovera, jutjat en un consell de guerra, s'aprecia que aquest fou processat i condemnat per la seva actuació al municipi de Sant Esteve Sesrovires el juliol de 1936, i no per la seva actuació posterior com a director dels Preventoris anteriorment citats. Llovera fou condemnat a trenta anys de presó, el 28 de novembre de 1939, acusat de «robos, daños, coacciones y reparto de armas para oponerse al triunfo del Movimiento Nacional», i encara que en la sentència es feia esment de la seva actuació com a director de presons, també hi constava que d'aquella etapa de la seva vida no se n'havia rebut cap denúncia ni cap declaració en contra. ${ }^{57}$ En el sumari hi havia, fins i tot, declaracions de diversos reclusos, moltes d'elles signades de manera collectiva, que certificaven el bon tracte que havien rebut personalment de Llovera. En definitiva, però, com també succeí en els casos ja vistos de Rossend Codina o Ramon Morelló, les declaracions favorables que aquests agents dels Serveis Correccionals van rebre no es van considerar a l'hora de dictar sentència perquè els càrrecs als quals s'enfrontaven no estaven relacionats amb la seva conducta a la presó sinó amb la seva actuació política.

Si ens fixem en les sentències dels casos consultats veurem que la condemna més elevada, la pena de mort, es va imposar als funcionaris que la justícia franquista creia responsables d'haver lliurat reclusos perquè fossin assassinats. En aquest cas, el Preventori de Girona reuniria un to-

55 http://www.memoriademocratica.org/dades/horafoscant/dades3.html.

56 Causa General, caixa 1632, exp. 1, AHN.

57 «Sumarísimo de urgencia número 2.612 instruido contra Juan Enric Llovera», ATMTT. 
tal de cinc condemnes de mort si tenim en compte la de Joan Llampallas, acusat per la seva actuació en aquell establiment a l'inici de la guerra, i la de Joan Fuster, que va ser commutada gràcies a les influències del bisbe de Girona, José Cartañá. En el cas del Preventori de Lleida, en el qual també van assassinar-se reclusos, no hi va haver, en canvi, cap sentència de mort. ${ }^{8}$ Aquest fet s'explicaria, segurament, perquè els funcionaris de Lleida acusats d'aquests càrrecs van argumentar que les sortides dels reclusos van fer-se d'acord amb unes ordres de les autoritats i també a causa d'un assalt dels milicians que no es va poder aturar. Això no obstant, cal destacar les condemnes de dotze anys que van rebre el director, Eduard Costa, i els funcionaris Narcís Garcés i Antonio Rueda, que no van ser acusats, doncs, d'haver afusellat aquells reclusos. Seria un exemple més de l'arbitrarietat de les condemnes, una de les característiques d'aquesta mena de procediments judicials. Dit altrament: era no poc habitual que s'imposessin càstigs diferents pel mateix tipus de delicte. Els exemples de Lleida i Girona suara esmentats mereixerien, sens dubte, una comparació més acurada i detallada, però sorprèn que cap dels funcionaris de Lleida fos condemnat amb la intensitat dels de Girona, quan a Lleida s'havien afusellat uns 145 presos i a Girona, en canvi, 13.

Per insistir encara més en la paradoxa d'aquesta situació, els funcionaris de presons que després de 1939 van esdevenir reclusos van haver de suportar durant el seu captiveri unes condicions molt més dures que no pas les que existien a les presons en les quals havien treballat. La disciplina, les condicions higièniques, alimentàries i de saturació de les presons franquistes després de 1939 no es podien comprar amb les dels preventoris i correccionals de la Generalitat. ${ }^{59}$ Les funcionàries del Correccional de Dones que van ser detingudes i empresonades a la mateixa presó on havien treballat van haver de dormir a terra, a les escales, als patis i fins

58 Pot trobar-se informació sobre aquests assassinats a Joan SAGUÉs SANJosé, Una ciutat en guerra, Lleida en la guerra civil espanyola (1936-1939) (Barcelona: Publicacions de l'Abadia de Montserrat, 2003), 286-287.

59 Per conèixer el món penitenciari del primer franquisme pot consultar-se els estudis d'Aram MONFORT, Barcelona 1939: Ocupació i repressió militar. El camp de concentració d'Horta i les presons de la ciutat (tesi doctoral, Universitat Autònoma de Barcelona, 2007) i Barcelona 1939: el camp de concentració d'Horta (Barcelona: L'Avenç, 2008). 
i tot als vàters de l'establiment. ${ }^{60}$ Sens dubte aquesta presó, que va sobrepassar les dues mil internes, estava molt allunyada d'aquell Correccional modèlic, amb capacitat per a cinc-centes recluses, que la Generalitat havia creat després d'enderrocar la vella presó de dones de Barcelona.

Per evitar els mecanismes de la depuració franquista, que s'analitzaran a continuació, alguns funcionaris dels Serveis Correccionals van fugir a l'exili, que d'alguna manera ja era per ell mateix una altra variant de la repressió que volien evitar. Els que en van retornar van haver de justificar el seu passat: sense ser culpables de res havien de demostrar, preventivament, la innocència. Les precaucions en aquell ambient repressiu de postguerra havien de ser molt grans. Un exemple el trobem en el cas d'Antoni Fort Duró, funcionari dels Preventoris de Lleida i Solsona. ${ }^{61}$ Antoni Fort va aconseguir escapar de la repressió després de 1939, i va fer-ho amb un exili de cinc mesos, durant el qual va poder preparar el retorn amb unes certes garanties. Des del camp de refugiats de Bram va aconseguir els avals de les autoritats franquistes de Biscarri, la seva localitat, que li van permetre tornar a casa sense haver de passar per un camp de classificació de presoners i presentats. Aleshores va obtenir els sòlids avals d'alguns dels reclusos que va conèixer a la presó. Però el motiu principal que li va permetre evitar el càstig, en aquell sistema repressiu on es fomentava la denúncia i la delació, va ser precisament l'absència d'acusacions en contra seva. A pesar d'això, extremant les precaucions, durant tota la seva vida guardaria els certificats favorables que li havien signat els reclusos de Lleida i Solsona. ${ }^{62}$

\section{Els expedients de depuració}

La depuració dels funcionaris va portar-se a terme en tots els cossos i a tots els membres de l'Administració de l'Estat. Mitjançant la Llei de 10 de febrer de 1939 «fijando normas para la depuración de funcionarios

6o Montserrat Duch Plana, «Presons de dones», dins Jaume Sobrequés, Carme Molinero \& M. SALA, ed., Els Camps de concentració i el món penitenciari a Espanya durant la Guerra Civil i el franquisme (Barcelona: Crítica, 2003), 585.

61 Aquest funcionari és el padrí de l'autor d'aquest article i el protagonista de l'obra de DuRó FORT, Guerra i exili d'un funcionari.

62 Duró Fort, Guerra i exili d’un funcionari, 249. 
públicos», l'Estat franquista pretenia «imponer sanciones adecuadas, según los casos, a los que incumpliendo sus deberes contribuyeron a la subversión y prestaron asistencia no excusable a quienes por la violencia se apoderaron, fuera de toda norma legal, de los puestos de Mando de la Administración». ${ }^{6}$ D’aquesta manera, doncs, si en els consells de guerra es castigava amb el delicte de rebellió militar haver romàs fidel a la legalitat republicana, en els processos depuradors es considerava «apoderarse de los mandos de la Administración» haver servit el govern legalment constituït des del corresponent lloc de feina.

Amb aquesta Llei de depuració, i la de 9 de febrer de 1939 de Responsabilidades Políticas, l'Estat franquista establia un mecanisme de complementarietat en el seu sistema repressiu. Així, a la repressió judicial, capitalitzada pels consells de guerra, s'hi afegia també l'administrativa. Aquesta complementarietat entre la via penal i la via civil que va donar-se en la repressió franquista queda evidenciada també en el cas dels funcionaris de presons. Alguns funcionaris van ser condemnats pels tribunals franquistes i tampoc van superar el procés depurador del cos de presons. Altres, que no havien estat jutjats pels tribunals, o que havien estat absolts, van ser igualment sancionats amb l'expulsió del cos i encara que no van ser condemnats a cap pena de presó no van poder exercir la que havia estat la seva professió mai més. Aquesta doble repressió, doncs, va fer que només els funcionaris més significats amb el bàndol franquista superessin amb impunitat aquesta maquinària repressiva. Un bon exemple d'això el trobem al Preventori de Lleida on els tres funcionaris més ben considerats pels reclusos de dretes, Marcelino Sallán Zozaya, Antonio Escrig Puerto i Cristòfor Pau Vaquer, no van ser objecte de cap sanció, mentre que la resta de la plantilla va ser depurada amb resultat desfavorable. ${ }^{64}$ En aquest cas cal destacar a més que els tres funcionaris s'havien quedat a Lleida el març de 1938 a esperar les tropes franquistes i que per aquest motiu van ser destituïts dels Serveis Correccionals. ${ }^{65}$ Si repassem els noms dels funcionaris readmesos per al servei que es publicaven al Boletín Oficial del Estado, veurem que al Preventori de Tarragona van ser

$63 \mathrm{BOE} 45$ (14 feb.1939), 856.

64 Ibídem, 117.

65 DOGC 105 (15 abr. 1938), 217. 
readmesos sis dels dotze funcionaris que hi prestaven servei el gener de 1939. ${ }^{66}$ En el quadre 2 es relacionen els noms dels funcionaris de presons que van exercir després de 1939, que s'han pogut obtenir consultant el BOE i les declaracions de la Causa General.

El procés depurador va depassar l'àmbit laboral i va esdevenir un element més de control del conjunt de la societat. La presumpció de culpabilitat era generalitzada i tal com afirma Jaume Claret en el seu estudi sobre la depuració franquista de la Universitat catalana: «En un món de justícia al revés, els encausats havien de demostrar la seva innocència i la falsedat de les acusacions. En principi tothom era culpable». ${ }^{67}$

La depuració dels funcionaris de presons a Catalunya va iniciar-se el 14 de febrer de 1939, el mateix dia que es publicava la llei que la regulava; no en va en el preàmbul es reconeixia que la conquesta de Barcelona, seu llavors del Govern republicà, era una de les seves motivacions. Poc després, sense instruir cap mena d'expedient, i d'acord amb la Llei de 10 de febrer de 1939, van separar-se del servei els primers funcionaris de presons exiliats, que «por su conducta al huir al extranjero desde Cataluña con las hordas rojoseparatistas, han demostrado ser contrarios al Glorioso Movimiento Nacional liberador de España». ${ }^{68}$

Cal destacar que en el cas de les presons, la depuració del seu personal va coincidir amb l'etapa de major població reclusa de tota la història d'Espanya, propiciada per la terrible repressió que va desencadenar-se després de 1939. El Cos de Presons va haver de fer front a aquest creixement sobtat dels interns amb una plantilla que havia disminuït en un cinquanta per cent per causa de la guerra i les depuracions. En moltes presons es van cobrir les places vacants amb familiars dels caídos durant la guerra, una mesura que a banda de resoldre el dèficit de personal garantia l'odi i la venjança dels nous funcionaris contra els vençuts. ${ }^{69}$ La mateixa dispo-

66 BOE 89 (3o març 1939), 1.801. Els funcionaris readmesos van ser Manuel Ceballos Gimeno, Félix Lozano Barambio, Ángel Oliete Martín, José Gallastegui Alegría, Joaquín Sancho Bel i Pilar Catalán García.

67 Jaume Claret i Miranda, La repressió franquista a la Universitat catalana (Vic: Eumo Editorial, 2003), 16. El concepte "justícia al revés" prové del mateix Ramon Serrano Súñer, artífex de l'entramat jurídic del franquisme; l'usà a Memorias. Entre el silencio y la propaganda (Barcelona: Planeta, 1977), 245.

68 BOE 66 (7 març 1939), 1.321.

69 Hernández Holgado, Mujeres encarceladas, 184. 
sició també s'havia aplicat a un altre cos repressiu, la policia, com s'ha vist en parlar del Rondín Antimarxista. Pel que fa a la cronologia del procés depurador, segons Hernández Holgado, aquest va comptar amb una etapa inicial, de 1939 a 1945, caracteritzada per una forta empenta, i va relaxar-se posteriorment a partir de 1945, fins a l'extrem que durant la segona meitat d'aquesta dècada van ser readmesos diversos funcionaris que havien estat inicialment separats del servei. ${ }^{70}$

D'acord amb la Llei de depuració del 10 de febrer de 1939 tots els funcionaris estaven obligats a presentar una declaració que comprenia les dades relatives a la seva actuació política, sindical i professional des de l'octubre del $1934 \cdot{ }^{71}$ Tota aquesta informació estava recollida en un qüestionari que s'havia de respondre per escrit i que constava de les següents preguntes:

1. Situación en que se encontrara y destino que desempeñare el día 18 de julio de 1936.

2. Si prestó su adhesión al Movimiento nacional y en qué fecha y forma lo efectuó.

3. Si prestó su adhesión al Gobierno rojo, a alguno de los autonómicos que de él dependían, o a las autoridades rojas, con posterioridad al 18 de julio, en qué fecha y en qué circunstancias, especificando si lo hizo en forma espontánea o en virtud de coacción.

4. Servicios prestados desde el 18 de julio de mil novecientos treinta y seis, indicando especialmente los destinos, tanto en su Cuerpo o servicio, como en otros, y los ascensos que hubiera obtenido, especificando los que hubieran sido de rigurosa antigüedad.

5. Servicios prestados en favor del Movimiento Nacional.

6. Sueldos, haberes o cualquier otra clase de emolumentos, percibidos desde la iniciación del Movimiento y concepto por el que se acreditaron.

7. Partidos políticos y entidades sindicales, a que ha estado afiliado, indicando la fecha de afiliación y en su caso, del cese: cotizaciones voluntarias o forzosas en favor de partidos, entidades sindicales o Gobierno, que haya 
realizado incluyendo en ellas los hechos a favor del Socorro Rojo Internacional, Amigos de Rusia y entidades análogas, aunque tuvieran carácter de partido político.

8. Si pertenece o ha pertenecido a la Masonería, grado que en ella hubiere alcanzado y cargos que hubiere ejercido.

9. Testigos que pueden corroborar la veracidad de sus afirmaciones y documentos de prueba que pueda presentar o enseñar.

Quan la conducta i actuació del funcionari quedava clara amb la pròpia declaració i els informes complementaris, l'instructor de l'expedient redactava un informe en el qual es proposava l'admissió del depurat sense sanció o bé, en cas contrari, la incoació de l'expedient per imposar la sanció que correspongués. La normativa recomanava començar la depuració «por los casos en que sea más patente la adhesión al Movimiento Nacional, con el doble objeto de que los funcionarios puedan ser utilizados rápidamente al servicio de la Administración y puedan también servir de testigos en otras investigaciones». ${ }^{72}$

Les sancions imposades podien anar des de la separació definitiva del servei, la inhabilitació per als llocs de comandament i confiança, el retard en l'obtenció d'ascensos entre un i cinc anys, i finalment el trasllat forçós amb prohibició de sollicitar vacants durant el període d'un a cinc anys. De totes les sancions, la que s'imposava amb més freqüència era la separació definitiva del servei i, per tant, l'expulsió del Cos de Presons. En aquest sentit, el Cos de Presons va esdevenir un dels organismes de l'Estat amb un major índex de depuració entre la seva plantilla, que superava àmpliament el percentatge dels expedients sancionadors en el servei de Correus que, situat en el 35\% del total, és considerat un dels més alts de tota l'Administració. ${ }^{73}$ Els exemples del Preventori de Lleida i la presó madrilenya de Ventas, estudiada per Fernando Hernández Holgado, exemplifiquen l'abast d'aquesta repressió funcionarial.

En els expedients de depuració consultats, que corresponen als funcionaris del Preventori de Lleida, encara que durant el transcurs de la guerra

72 BOE 45 (14 feb. 1939), 857.

73 Juan Carlos Bordes MuÑoz, «La depuración político-social en Correos y Telégrafos», dins Cuesta, dir., La depuración de funcionarios bajo la dictadura, 158. 
van ser destinats a altres presons catalanes, es pot veure la tipologia de les acusacions. Majoritàriament responien a motius personals o ideològics. La funcionària Rosa Teresa va ser acusada, per exemple, de casar-se amb un comisario rojo. ${ }^{74}$ L'acusació més comuna, però, va ser la d'haver abandonat la presó de Lleida abans de l'entrada de les tropes franquistes, fet que va considerar-se com una mena d'abandó del servei per causa d'haver obeït ordres d'unes autoritats illegítimes contràries al Movimiento Nacional. La ideologia marxista dels funcionaris i maltractar reclusos també van ser dos càrrecs que van repetir-se en aquells expedients, sobretot la segona, ${ }^{75}$ una acusació que en certs casos es basava en les declaracions de terceres persones, com demostra l'expedient de Joan Regués:

Era socio del Centro Juventud republicana de Lérida, maltrató a los presos de derechas, aconsejando a los milicianos que exterminasen pronto a todas las buenas personas llegando a decir en la Prisión de Lérida: «tendrían que fusilar a todos los que han votado a las derechas» y que «de los allí encarcelados no debía escapar ninguno». ${ }^{6}$

Aquests processos depuradors van caracteritzar-se per la indefensió jurídica de l'encausat i l'arbitrarietat de les acusacions, de manera que funcionaris amb actuacions anàlogues o similars van rebre acusacions i càstigs diferents. A més, sovint, les acusacions no estaven basades en fets provats i sí, en canvi, en supòsits i denúncies infundades.

Un cop expedientats, els funcionaris podien sollicitar la revisió del seu cas si consideraven que existien motius suficients per poder modificar la sanció que havien rebut. Així, Joan Regués va demanar que es reobrís el seu expedient en dues ocasions, l'any 1941 i l'any 1947. En ambdues la Dirección General de Prisiones va confirmar la sanció imposada, amb l'agreujant que la resolució de la darrera va fer-se esperar fins a l'any 1951. Tot i que la justícia franquista no va represaliar penalment Joan Regués,

74 Expedient de depuració de Rosa Teresa Gorgas, FDGIP, AGMI.

75 Aquesta acusació sumada a altres va constituir, per exemple, el plec de càrrecs contra Narcís Garcés: «Primero, haberse portado muy mal en su trato con los presos de derechas y con los elementos de orden. Segundo haber huído de Lérida abandonando la prisión a la entrada de las Tropas del Gloriosos Ejército Nacional»; Expedient de depuració de Narcíso Garces Fredes, FDGIP, AGMI.

76 Expedient de depuració de Joan Regués Bonany, FDGIP, AGMI. 
la seva actuació a les presons de la zona lleial a la República no podia quedar impune, com destacava l'inspector de presons en l'informe emès el 1951 en referir-se a la seva conducta: «Esta conversión al enemigo o, si se quiere, esta aceptación de la doctrina del antipatriotismo y de la perversidad roja, no tienen justificación posible».77 Regués va ser un d'aquells funcionaris de l'Estat que en ingressar als Serveis Correccionals va gaudir de la confiança de la Generalitat i va ascendir. El càstig que se li havia imposat el 1939 buscava, en definitiva, sancionar la progressió de la seva carrera dins dels Serveis Correccionals ja que de funcionari de presó havia passat a director. En la mateixa situació es va trobar Jaume Miquel Palau, que de cap d'una presó de partit judicial havia passat a inspector i va ser depurat acusat d'«haber aceptado un ascenso extraño al movimiento natural de la escala». ${ }^{78}$ Encara que segons la legalitat franquista, a partir de la Llei del 5 d'abril de 1938, la Generalitat havia estat abolida, amb aquestes actuacions queda evidenciada un cop més la retroactivitat de la justícia franquista que castigava l'ascens de dos funcionaris des de l'òptica d'una escala funcionarial a la qual ja no pertanyien des que havien ingressat als Serveis Correccionals.

\section{Recapitulació}

Aquesta aproximació a la repressió dels funcionaris de les presons catalanes confirma el mecanisme de complementarietat entre la via penal i la via administrativa que va caracteritzar la repressió franquista. Molts funcionaris de presons van ser represaliats al mateix temps a través dels consells de guerra i dels expedients de depuració, mentre que uns altres que havien eludit alguna de les dues jurisdiccions, penal o administrativa, no van poder deslliurar-se de l'altra.

En referència a la localització d'aquesta repressió, cal observar que va ser major en els centres penitenciaris on durant la guerra es van assassinar reclusos dretans o identificats amb els sollevats; són els casos dels Preventoris de Lleida i Girona. Al mateix temps, però, encara que el sistema repressiu fos implacable, es confirma també l'arbitrarietat d'aquesta

77 Ibídem.

78 BOE 123 (3 maig 1939), 2.418. 
repressió, perquè en altres indrets amb víctimes dins de la presó, com per exemple al Preventori de la Seu d'Urgell, no hi ha constància de l'actuació de la justícia franquista. Fins i tot a la presó de Lleida, dos dels funcionaris represaliats d'aquell centre no tenien cap responsabilitat en els assassinats, i en el cas de Sant Feliu de Llobregat, on també es van produir assassinats, va commutar-se la condemna a mort del director del Preventori.

Pel que fa a les víctimes d'aquesta repressió, s'aprecia també una major repressió en els casos dels funcionaris de més nivell, com els directors dels establiments, que la justícia franquista va castigar per haver ocupat càrrecs directius dins de l'administració republicana. En els casos dels funcionaris més baixos de l'escalafó, hi ha un nivell més alt de readmissió en el servei sempre que no existís cap denúncia en contra. Precisament en el camp dels funcionaris que van superar el procés depurador, en el Preventori de Tarragona es detecta una elevada confirmació en el càrrec dels seus funcionaris per les noves autoritats franquistes.

Finalment, cal remarcar, sobretot, la importància de les denúncies dins d'aquesta mecànica repressiva de postguerra. La repressió franquista va ser generalitzada però no podia actuar d'ofici en tots els casos i aquí és on cobraven rellevància les denúncies que permetien l'activació o l'inici d'aquesta repressió. Els funcionaris dels Serveis Correccionals que anteriorment no ho havien estat de l'Estat no van ser depurats com a funcionaris perquè la Generalitat ja havia estat abolida; en canvi molts d'ells van ser jutjats en consells de guerra a causa de les denúncies dels exreclusos. 


\section{Apèndix}

\section{QUADRE 1. Funcionaris de presons represaliats pel franquisme ${ }^{1}$}

\begin{tabular}{lll} 
Nom & Repressió & Font \\
\hline Preventori de Barcelona & & \\
\hline Juan Antonio Rodríguez Huertas & Baixa del servei & BOE 3/5/1939 \\
\hline Rossend Codina Ramon & Consell de guerra & Consell de guerra \\
\hline Daniel Cochs Reig & Condemnat a mort & $\begin{array}{l}\text { Alba DíAz \& Elena LEDESMA, Cartes } \\
\text { de condemnats a mort pel franquisme } \\
\text { (Valls: Cossetània, 2010), 45. }\end{array}$ \\
\hline Francesc Vilà Costafreda & Condemnat a mort & $\begin{array}{l}\text { CoRBALÁn GiL, Justícia, no venjança, } \\
\text { 248. }\end{array}$ \\
\hline Antoni Mayora Torrent & Exili & Causa General
\end{tabular}

Preventori de Barcelona núm. 2

\begin{tabular}{lll}
\hline Joan Regués Bonany & Baixa del servei & BOE 21/1/1940 \\
\hline Sebastià Nicolau Ferrando & Consell de guerra & Consell de guerra \\
\hline Anastasio Gómez Cardoso & Baixa fins a 1943 & BOE 23/1/1943 \\
\hline Pere Sabater Carbonell & Fugit & Causa General \\
\hline Josep Castan Velázquez & Condemnat & Consell de guerra \\
\hline Francesc Oromí Capell & Consell de guerra & Consell de guerra \\
\hline José Miralles Gausachs & Consell de guerra & Consell de guerra \\
\hline Josep Bastus Oliveres & Consell de guerra & Consell de guerra \\
\hline Joan Prats Prats & Detingut & Causa General
\end{tabular}

\section{Pavelló Hospital}

\begin{tabular}{lll}
\hline Joan Enric Llobera Martí & Condemnat & Consell de guerra \\
\hline Arseni Mesa Garcia & Baixa del servei & BOE 29/6/1939 \\
\hline Emili Morató Vives & Detingut & Consell de guerra
\end{tabular}

1 La recopilació dels funcionaris represaliats respon a una primera cerca que permet, en tot cas, aproximar-se a uns resultats que han de ser contrastats i sotmesos a una anàlisi més acurada. 
Nom

Repressió

Font

Correccional de Dones

\begin{tabular}{|c|c|c|}
\hline Isabel Peyró Polo & Rebel/Exili & La Vanguardia Española 10/2/1943 \\
\hline Joaquima Mani Barneda & Declarada rebel & La Vanguardia Española 10/2/1943 \\
\hline Josep Martí Feced (metge) & Exili & http://www.metgesalexili.cat \\
\hline Concepció Solà Ferrer & Declarada rebel & La Vanguardia Española 10/2/1943 \\
\hline Pura García Gómez & Declarada rebel & Consell de guerra \\
\hline Margarita López Otazu & Declarada rebel & La Vanguardia Española 10/2/1943 \\
\hline Joaquima Mallorquí Pujol & Declarada rebel & La Vanguardia Española 10/2/1943 \\
\hline Elionor Barnolas Fernández & Reclamada. Jutjat & La Vanguardia Española 10/2/1943 \\
\hline Rosa Sans Orenga & Declarada rebel & La Vanguardia Española 10/2/1943 \\
\hline Maria Fornes Paralta & Reclamada. Jutjat & La Vanguardia Española 1/8/1943 \\
\hline Josefa Coll Vila & Declarada rebel & La Vanguardia Española 10/2/1943 \\
\hline Rosa Teresa Gorgas & Baixa del servei & BOE 29/6/1939 \\
\hline Josefa Barrera & Declarada rebel & La Vanguardia Española 10/2/1943 \\
\hline Josefina Mani de Peypoch & Declarada rebel & La Vanguardia Española 10/2/1943 \\
\hline Josefina Garcia Pastor & Declarada rebel & La Vanguardia Española 10/2/1943 \\
\hline Josefina Gómez Márquez & Declarada rebel & Consell de guerra \\
\hline Vicenta Pérez Devesa & Reclamada. Jutjat & La Vanguardia Española 10/2/1943 \\
\hline Dolores Servent & Reclamada. Jutjat & La Vanguardia Española 10/2/1943 \\
\hline Francisca Baquero Campos & Reclamada. Jutjat & La Vanguardia Española 10/2/1943 \\
\hline
\end{tabular}

Correccional de Figueres

Lluís Romaguera Balart

Consell de guerra http://familiarsrepresaliatsfranquisme. entitatsfigueres.cat

Llorenç Montcanut Valls Exili Gazeta de los Estados Unidos de Venezuela 23.119 (13 abril 1950).

\section{Preventori de Girona}

\begin{tabular}{lll}
\hline Joan Rius Gatell & Exili & CLARA, Girona 1939, 64-94. \\
\hline Manuel Suárez Garcia-Labrador & Condemnat a mort & CLARA, Girona 1939, 64-94. \\
\hline
\end{tabular}




\begin{tabular}{|c|c|c|}
\hline Nom & Repressió & Font \\
\hline Josep M. Butiñà Guimerà (metge) & Sanció temporal & $\begin{array}{l}\text { Francesc X. CARRERAS DE CABRERA \& } \\
\text { Jordi PUJIUlA I RIBERA, «Depuració de } \\
\text { la conducta política i social dels metges } \\
\text { gironins. 1939-1946», Gimbernat } 53 \\
\text { (2010): 179-193. }\end{array}$ \\
\hline Rafael Espejo Gabarron & Condemnat a mort & Clara, Girona 1939, 64-94. \\
\hline Josep Ventura Barceló & Condemnat a mort & Clara, Girona 1939, 64-94. \\
\hline Joan Fuster Cuyàs & Mort (commutada) & Clara, Girona 1939, 64-94. \\
\hline
\end{tabular}

\section{Preventori de Lleida}

\begin{tabular}{lll}
\hline Joaquín Morcillo Núñez & Baixa temporal & Expedient depuració \\
\hline Julio Aragonés Marín & Baixa temporal & Expedient depuració
\end{tabular}

\section{Preventori de Manresa}

\begin{tabular}{|c|c|c|}
\hline Ángel Pedret Segura & Exili & Causa General \\
\hline Joan Pujol Carol & Condemnat & Causa General \\
\hline Ángel Armada Martínez & Detingut & Causa General \\
\hline Joan Espinalt Berenguer & Consell de guerra & La Vanguardia Española 16/2/1939 \\
\hline Ramon Poch Casanovas & Exili & $\begin{array}{l}\text { Josep Lluís NEGREIRA VERJILLOS, } \\
\text { Del somni republicà a la barbàrie } \\
\text { franquista. Cerdanyola del Vallès } \\
\text { (1936-1952) (Barcelona: Universitat } \\
\text { Autònoma de Barcelona, 2006), } 124 \text {. }\end{array}$ \\
\hline
\end{tabular}

\section{Correccional de Mataró}

\begin{tabular}{lll}
\hline José Vicente Sebastián & Baixa del servei & BOE 3/5/1939 \\
\hline Eduard Meléndez Gardenyes & Detingut & Causa General \\
\hline Enric Ferrer Llagostera & Consell de guerra & Causa General \\
\hline Ernest Clariana Josep & Consell de guerra & Causa General \\
\hline Nicolau Verdaguer Claus & Consell de guerra & Causa General \\
\hline Joan Sariol Español & Detingut & Causa General \\
\hline Pere Gallardo Galera & Exili & Causa General
\end{tabular}


Nom

Preventori de Sabadell

Higini Navarro Abadal

Empresonat

Preventori de Solsona

\begin{tabular}{lll}
\hline Eduard Costa Julià & Condemnat & Consell de guerra \\
\hline Artur de Lera Darnell & Baixa del servei & BOE 29/6/1939 \\
\hline Ramon Morelló Almoiner & Consell de guerra & Consell de guerra
\end{tabular}

\section{Preventori de Terrassa}

Feliu Prats Granyé Exili Causa General

\section{Correccional de Vic}

\begin{tabular}{lll}
\hline Lluís Grau Castells & Exili & $\begin{array}{l}\text { http://prodavinci.com/2009/07/03/ } \\
\text { artes/testimonio }\end{array}$ \\
\hline Pere Llampallas Camarasa & Condemnat a mort & \begin{tabular}{l} 
CLARA, Girona 1939, 64-94. \\
\hline
\end{tabular} \\
\hline
\end{tabular}

José Hormigo Sánchez

Denunciat

Causa General

Direcció General

\begin{tabular}{lll}
\hline Jaume Miquel Palau & Baixa del servei & BOE 3/5/1939 \\
\hline Antoni Devesa Bayona & Condemnat a mort & http://fal.cnt.es \\
\hline Magí Salla Targa & Consell de guerra & La Vanguardia Española 16/6/1943
\end{tabular}

Sense ubicació

\begin{tabular}{lll}
\hline Joan Feliu Miró & Exili & Causa General \\
\hline Guillermo Viñuales Pano & Baixa del servei & BOE 3/5/1939 \\
\hline Francisco López Navarro & Baixa del servei & BOE 29/6/1939 \\
\hline Antonio Aznar Linares & Baixa del servei & BOE 29/6/1939 \\
\hline Manuel Cuenca Martínez & Baixa del servei & BOE 29/6/1939 \\
\hline Virgilio Zapata Gutiérrez & Baixa del servei & BOE 29/6/1939 \\
\hline Alfredo Tierno Goñi & Baixa del servei & BOE 29/6/1939 \\
\hline
\end{tabular}


QUADRE 2. Funcionaris admesos sense sanció després de 1939

\begin{tabular}{|c|c|c|c|}
\hline Nom & Font & Nom & Font \\
\hline \multicolumn{2}{|l|}{ Preventori de Barcelona } & Teresa Suau Gil & BOE 7/5/1939 \\
\hline José Lobit Fernández & BOE 30/3/1939 & \multirow{2}{*}{$\begin{array}{l}\text { Magdalena Larrondo } \\
\text { Oquendo }\end{array}$} & \multirow[t]{2}{*}{ BOE 3/5/1939 } \\
\hline Ramon Marcual Alemany & Causa General & & \\
\hline Manuel Azuara Petrola & Causa General & \multirow[t]{2}{*}{$\begin{array}{l}\text { Adelmira Mirasierras } \\
\text { López }\end{array}$} & \multirow[t]{3}{*}{ BOE 3/5/1939 } \\
\hline Antoni de Mena Polo & BOE 19/6/1939 & & \\
\hline José Moya Rodríguez & Causa General & Correccional de Figueres & \\
\hline Manuel Alejandre Sanz & Causa General & \multirow{2}{*}{$\begin{array}{l}\text { Francisco Pintor Ruiz } \\
\text { Preventori de Girona }\end{array}$} & \multirow[t]{2}{*}{ BOE 7/5/1939 } \\
\hline Félix González Hernández & Causa General & & \\
\hline Miguel Lozano Herrero & Causa General & \multirow{2}{*}{$\begin{array}{l}\text { Julio Martín-Criado } \\
\text { Domingo }\end{array}$} & \multirow[t]{2}{*}{ BOE 7/5/1939 } \\
\hline José de Mesa García & BOE 7/5/1939 & & \\
\hline Miguel Queralt Sales & BOE 7/5/1939 & Isidro Escrich Bolinches & BOE 7/5/1939 \\
\hline Mariano Lucas Pascual & BOE 7/5/1939 & \multirow[t]{2}{*}{ José Castellano Pruñonosa } & \multirow[t]{2}{*}{ BOE 19/6/1939 } \\
\hline Daniel Luis Gómez & BOE 3/5/1939 & & \\
\hline Telesforo Llobet Morata & BOE 7/5/1939 & \multirow{2}{*}{ José Castro Muntanyola } & \multirow{2}{*}{ BOE 8/10/1951 } \\
\hline $\begin{array}{l}\text { Federico Muñoz de } \\
\text { Lamadrid }\end{array}$ & BOE 3/5/1939 & & \\
\hline Leopoldo Rubí Álvarez & BOE 3/5/1939 & Preventori de Reus & \multirow{2}{*}{ BOE 30/10/1944 } \\
\hline Adolfo Sánchez Bragado & BOE 3/5/1939 & Josep Camarasa Arrufat & \\
\hline Enrique Cáceres Fumanal & Causa General & \multirow{2}{*}{$\begin{array}{l}\text { Artur Cortés Meras } \\
\text { Preventori de Sabadell }\end{array}$} & \multirow[t]{2}{*}{ BOE 7/5/1939 } \\
\hline Nicolás Municio Barahona & BOE 3/5/1939 & & \\
\hline Gregorio Varea Gómez & BOE 3/5/1939 & \multirow{3}{*}{$\begin{array}{l}\text { Víctor Uriel Esteban } \\
\text { Preventori de la Seu d'Urgell }\end{array}$} & \multirow{2}{*}{ BOE 7/5/1939 } \\
\hline Francisco Álvarez Pauleta & Causa General & & \\
\hline \multirow{2}{*}{ Eduardo Safont Bou } & \multirow{2}{*}{ Causa General } & & \\
\hline & & Josep Rafel Olivé & Causa General \\
\hline \multicolumn{2}{|c|}{ Preventori de Barcelona núm. 2} & \multirow[t]{2}{*}{ José Moliner Bertran } & \multirow[t]{2}{*}{ BOE 7/5/1939 } \\
\hline Francisco Año Ferrus & BOE 19/6/1939 & & \\
\hline \multirow[t]{2}{*}{ Juan García Maestranza } & BOE 19/6/1939 & Preventori de Tarragona & \\
\hline & & José Gallastegui Alegría & BOE 30/3/1939 \\
\hline Correccional de Dones & & Félix Lozano Barambio & BOE 30/3/1939 \\
\hline
\end{tabular}




\begin{tabular}{|c|c|c|c|}
\hline Nom & Font & Nom & Font \\
\hline Angel Oliete Martín & BOE 30/3/1939 & \multirow{2}{*}{\multicolumn{2}{|c|}{ Direcció General }} \\
\hline \multirow{2}{*}{ Manuel Ceballos Gimeno } & \multirow{2}{*}{ BOE 30/3/1939 } & & \\
\hline & & \multirow{3}{*}{$\begin{array}{l}\text { Miquel Morey Cabrer } \\
\text { Sense ubicar }\end{array}$} & \multirow[t]{3}{*}{ BOE 3/5/1939 } \\
\hline Joaquín Sancho Bel & BOE 30/3/1939 & & \\
\hline \multirow{2}{*}{ Pilar Catalán García } & \multirow{3}{*}{ BOE 30/3/1939 } & & \\
\hline & & Joaquín Mauri-Vera Elías & BOE 30/3/1939 \\
\hline Preventori del Vendrell & & Juan Bautista Lorca & BOE 30/3/1939 \\
\hline \multirow{2}{*}{ Enric Ros Gálvez } & \multirow{3}{*}{ BOE 29/6/1939 } & Lanovas & \\
\hline & & Pedro Sanz Rodríguez & BOE 30/3/1939 \\
\hline Preventori de Lleida & & Enrique Fosar Bayarri & BOE 7/5/1939 \\
\hline Marcelino Sallan Zozaya & BOE 4/4/1939 & Salvador López Sapiña & BOE 7/5/1939 \\
\hline Antonio Escrig Puerto & Causa General & Leonardo Feito López & BOE 19/6/1939 \\
\hline \multirow[t]{2}{*}{ Cristòfor Pau Vaquer } & \multirow[t]{3}{*}{ Causa General } & José Gascón Esteve & BOE 19/6/1939 \\
\hline & & Antonio Sirat Lafont & BOE 19/6/1939 \\
\hline Correccional de Mataró & & Francisco González & BOE 19/6/1939 \\
\hline $\begin{array}{l}\text { Lorenzo Serramitjana } \\
\text { Roura }\end{array}$ & BOE 3/5/1939 & Sánchez & \\
\hline
\end{tabular}

